\title{
Social Protest in Russian America
}

\author{
ANDREI V. GRINËV \\ TRANSLATED BY RICHARD BLAND
}

\begin{abstract}
This article analyzes social protest in the Russian colonies in Alaska and Northern California. The main reasons for protests were the actions of the colonial administration or abuse by its representatives, along with dissatisfaction with the financial situation, rules, conditions, and remuneration for labor, as well as shortages of commodities and food for a considerable part of the population of the Russian colonies. Protest activity in Russian America was relatively insignificant, and its primary forms were complaints, minor economic sabotage, and desertion. Most protest acts took place during the 1790s-1800s, when the colonial system was formed, and exploitation of dependent natives and Russian promyshlenniki (hired hunters of fur-bearing animals) reached its peak. The representatives of the Russian-American Company who managed Alaska from 1799 on tried to block protest activity and not allow open displays of dissatisfaction, since the result could hinder trade, business, and finally, profits and its image in the eyes of the tsar's authorities.
\end{abstract}

Keywords: colonization of Alaska, protest practice, Russian America, Russian-American Company, social protest

$\mathrm{T}$ he problem of social protest in Russian America, that is Alaska, from 1741 to 1867 has not been an object of special study in historiography. The sources of information in this article about social protests in Russian America are primarily archival and published documents, memoirs, and travel notes of seafarers, travelers, missionaries, and officials, as well as an extensive range of scholarly literature by Russian and American authors (see, e.g., Sarafian 1971). This article presents a chronology of examples of social protest in the region to present a picture of the characteristic trends.

During different time periods social protest has been manifested in a variety of forms throughout the world. For example, its modern forms, such as demonstrations, picketing, boycotts, hunger strikes, 
and blocking transportation routes, were unusual in Russia of the eighteenth-first half of the nineteenth century. The set of protest practices was quite different, ranging from passive sabotage of the orders of the leadership, refusal to work, presentation of demands and requests, usually in the form of filing complaints, petitions, and appeals, and flight from the place of permanent residence to more drastic measures such as taking representatives of authority hostage, spontaneous local rebellion, and finally, armed uprising (Dement'eva 2013; Kelas'ev, Kazakov, Leyes 2006). Sources that cause protests range from tyranny of the local administration or landlord, adoption of unpopular laws, increase in economic oppression, and so on. Overall, the more active kinds of social protests were not characteristic of Russia (the usual forms of protest were complaints, denunciations and economic sabotage), where the population was crushed by the power of the punitive state machine and the level of education and self-awareness of the bulk of the people was extremely low, and the official religion of the Orthodox Church strongly contributed to the suppression of potential protest attitudes, calling for patience, humility, and forgiveness. In addition, it was the priests who read and interpreted the royal decrees to almost all the illiterate population during the church service, thereby forming loyalty to the authorities among urban and rural residents (Mironov 2015: 482-483). Therefore, passive forms of protest prevailed. And only when the state weakened, due to certain historical circumstances, or its pressure (or the coercion and violence of its local representatives) became unbearable did the population or individual social groups or persons resort to certain actions of violent social protest. The underlying reasons for the specifics of Russian protest lie in the very nature of the socioeconomic system that prevailed in a country. The lack of proper institutions of private forms of property and its legal guarantees under the rule of the state in all spheres of life of Russian society produced such features as passivity, laziness, blind adherence to any orders by authority, conformism, and absenteeism, which stemmed from an absence of personal freedom and thus a lack of interest in the results of this labor. Thus, such a social structure could not contribute to social activity nor the growth of feelings of social protest.

\section{The Discovery of Alaska and the First Social Protests}

What was the case, then, in Russian America? It turns out that social protest was also an infrequent phenomenon there. After completion 
of the Second Kamchatka Expedition of V. I. Bering and A. I. Chirikov in 1741, Russian promyshlenniki (hunter-trappers) rushed to the islands and lands, rich in fur-bearing animals, discovered by the expedition for the purpose of procuring the valuable furs, which then went part to the Russian market and part to China in exchange for tea. The promyshlenniki did not move to the Commander Islands, closest to Kamchatka, and then to the farther Aleutian Islands and Alaska by themselves, but rather in the composition of merchant companies that resourceful Siberian entrepreneurs organized by combining capital for the construction and equipping of seagoing vessels and recruitment of crews, mariners, and foremen-stewards responsible for conducting the hunt and preservation of the cargo. For their part, the Kamchatka and then the Okhotsk authorities kept an "eye of the sovereign" on the merchant ships, usually in the person of a Kamchatka sergeant or Cossack enlisted to monitor the behavior of the crew and to oversee the collection of tribute (the acquisition of furs for the royal treasury) from the local natives (Makarova 1968: 108).

In preparation for a hunting voyage the merchant-entrepreneurs, promyshlenniki, stewards, and sailors concluded a special agreement-a "gross contract" (AVPRI, f. RAK, op. 888, d. 123, 1. 309-310 ob.; Makarova 1968: 164-181). ${ }^{1}$ Stipulated in it were concerns regarding the hunting activity of the company and the number of so-called shares and their categories. The basic gross shares were the shares of the main participants of the company who invested their capital in construction and equipping of ships. Acquired furs were distributed, correspondingly, to the number of gross shares. These shares were divided into three categories. The most common form was the half-share system, wherein the working man employed by the merchant received half of all the furs he brought in, and half went to the owner who employed him. The popularity of such an economic relation was in the fact that the half-share system maximally stimulated the promyshlennik to acquire as many furs as possible and, correspondingly, receive a larger income for his half of the share.

Despite the elements of debt bondage the promyshlennikimany of whom were sent on a voyage already being debtors to the merchant-entrepreneurs-being civilians, maintained a certain share of independence. This was especially manifested on the offshore islands far from the owners of the trading companies and the Kamchatka administration, where the hunting workers sometimes, on their own initiative, displaced the navigators and stewards, selecting their own candidates in their place, and often violating the requirements of the 
state administration to treat the inhabitants of the Pacific islands gently. The protest of the promyshlenniki was expressed in the refusal to obey the orders of the navigator or steward if they were contrary to their interests and especially if they went beyond the bounds of the gross contract. Therefore, to prevent disobedience the promyshlenniki sometimes had to sign that they would unquestionably obey the navigator's orders during the voyage, and during the land hunting those of the steward (ARGO, razr. 60, op. 1, d. 2, 1. 13, 22). But this did not always help prevent a mutiny, since much depended both on the composition of promyshlenniki and on the willpower and determination of the leaders. For example, during the hunting expedition in 1777-1782 most members of the crew of the ship Sv. Andrei Pervozvannyi rebelled against the steward K. A. Samoilov, refused to hunt for furs, and removed him from control, selecting their henchmen in his place, which ultimately led to shipwreck and complete disorganization of the crew (ARGO, razr. 60, op. 1, d. 2, 1. 134-136). Thus, the destructive protest of the promyshlenniki led the company to economic losses.

In the sources known to us (i.e., written archival sources), such form of passive social protest as desertion is only rarely mentioned. The fact was that there was nowhere for promyshlenniki to flee: to the north and south of the chain of Aleutian Islands stretched the boundless Pacific Ocean, and to hide on the relatively small islands of the Aleutian chain among the sometimes hostile population was more than problematic. Only Siberian natives-Kamchadal (Itel'men), Koryak, Yakut, Evenk, Buryat - who had become part of crews of hunting ships, occasionally resorted to desertion (Grinëv 2018a: 137-138). They often became the objects of economic discrimination, receiving less than the Russian promyshlenniki, and were also subjected to insults on racial-ethnic grounds. Therefore, in the case of substantial harassments as a sign of protest they sometimes decided to flee. Thus, in 1752, before the return to Kamchatka of the crew of the ship Sv. Pëtr, two Kamchadal and one Koryak deserted (ARGO, razr. 60, op. 1, d. 2, 1. 15). According to this archival source, based on the explanation of the Koryak, the hope of procuring more furs for payment of debts forced them to leave the crew). Then, three more Kamchadal fled the ship Sv. Boris $i$ Gleb that belonged to the merchant Trapeznikov's company. After some time, the local Aleuts killed four of the Kamchadal "for violence" 2 against women, and one of the Kamchadal and the Koryak managed to be rescued and then returned to Kamchatka in 1755 on the ship Sv. Ioann of the company of the merchant Kholodilov (ARGO, razr. 60, op. 1, d. 2, 1. 34). 
An even more ambitious scale of desertion took place in 1756, when the sailor Pëtr Bashmakov (known for his violent temper) began his voyage on the ship Sv. Pëtr $i$ Pavel to the islands in the central part of the Aleutian archipelago, where twelve Kamchadal absconded with the ship. Bashmakov and Cossack Maksim Lazarev set off in pursuit of them in a baidara with twelve promyshlenniki. On the way they landed at thirteen islands, and on the last one they discovered the bodies of five fugitives, murdered evidently by the Aleuts. What became of the remaining deserters is unknown since after their frightful find Bashmakov and Lazarev stopped searching and returned to the ship (AVPRI, f. RAK, op. 888, d. 6, 1. 89 ob.). Such cases led to the Kamchadals and representatives of other Siberian peoples beginning to abandon fleeing. Desertion by non-Russian peoples forced some Russian merchants to reduce their number in the crews of hunting ships. For example, the head of the merchant union, Afanasii Chebaevskii, upon equipping the boat Sv. Ioann Predtecha in 1762, was afraid to take many Kamchadals in his crew-who, according to the source, at times were known to escape in the islands-and instead hired on twice as many Russian promyshlenniki (ARGO, razr. 60, op. 1, d. 2, 1. 52). After a large uprising of the Aleuts of the Fox Islands in 1763-1764, any mention of desertion in the Aleutian Islands almost disappears in historical documents-this was too dangerous, and after final subjugation of the Aleuts by Russian promyshlenniki in the 1770s—senseless. In 1781 the Solikamsk merchant Ivan Vtorushin and the promyshlennik Perfil'ev, who were part of the crew of the ship Sv. Izosim $i$ Savvatii, persuaded several comrades to flee to some foreign port upon the ship's return to Okhotsk (ARGO, razr. 60, op. 1, d. 2, 1. 137-138; Grinëv 2018a: 138). But this attempt ended unsuccessfully with the death of the main instigators and can hardly be considered a manifestation of social protest.

\section{Increase in Social Protests in Russian America}

At the beginning of the 1780s Russians had mastered the Aleutian chain and subjugated the local residents, forcing them to pay tribute to the tsarist treasury and to hunt sea otters (sea beavers) and other valuable fur-bearing animals for the representatives of the merchant companies. In 1784 the well-known merchant G. I. Shelikhov established on Kodiak Island at the southern shore of Alaska the first permanent Russian settlement in America. Soon new strongholds of Russians appeared on the American mainland itself in the region of the Kenai Peninsula, 
which was inhabited by the Indigenous Dena'ina nation (Tanaina or Kenai people, as the Russians called them) and the Chugach group of the Alutiiq people, who lived more to the south along the shores and islands of Prince William Sound. Here representatives of the company of the wealthy merchant P. S. Lebedev-Lastochkin (a Russian from Yakutsk) became established. In September 1790 he sent there the galliot Sv. Georgii (Tikhmenev 1863: 2:51) from Okhotsk led by the steward Grigorii Konovalov, who soon after arrival on the Kenai Peninsula became infamous for his abuses and violence toward not only the local natives, but also his own subordinates (Grinëv 2018b: 181-182, 204). The affair ended by the Lebedev people, seizing Konovalov and, placed in chains, handing him over to the leader of the Shelikhov company, A. A. Baranov, on Kodiak for removal to Okhotsk on the galliot Sv. Mikhail in May 1792 (Tikhmenev 1863: 2:50-57). However, it is possible that this social protest was provoked by Baranov to rid himself of a dangerous competitor. His master Lebedev-Lastochkin denied a denunciation of Baranov regarding Konovalov, indicating that complaints about Konovalov came from only twelve people and not from the whole crew of the galliot. In 1794 Konovalov was returned by the owner to America in the same rank, where the chosen steward Amos Balushin managed in his place at this time the artels of Lebedev people (ARGO, razr. 60, op. 1, d. 2, 1. 52).

In this same year, monks of the Spiritual Mission arrived from Russia to Kodiak to convert the local natives to Orthodoxy, as well as the posel'shchiki (settlers) - several dozens of exiles, sent by the administration to the Shelikhov company for development in America of crafts and agricultural production. These settlers brought no little trouble to Baranov. Having just become established on Kodiak and having faced difficulties and hardships there, the settlers began to show discontent, did not want to work, and refused to submit to the steward (prokazchik [junior manager]) I. G. Polomoshnyi, even threatening to kill him. Finally, they organized a conspiracy for the purpose of armed seizure of a ship, on which they intended to reach the Kuril Islands where some of their comrades had been sent. This was risky since none of the settlers possessed any skills at seamanship (Grinëv 2013). Even if they succeeded in their plan, they would have to force the crew of the ship they seized to take the ship to the Kurils, which was fraught with repetition of the situation with the ship Sv. Izosim $i$ Savvatii in 1781 as discussed above. Baranov uncovered the conspiracy in time: by his order three of the instigators were severely punished and sent to a distant artel (AVPRI, f. Gl. Arkhiv II-3, 1787-1796, op. 34, d. 1, 1. 16; Tikhmenev 1863: 
2: 95). Thus, social protest of the settlers, which nearly ended in open rebellion, was suppressed by the governor even before its realization. Though possessing an enduring will, personal courage, and remarkable abilities, Baranov held his subjects in submission with an iron hand. Arriving in Alaska back in 1790 as the head of Shelikhov's company, Baranov later became a central figure in the history of Russian America, who in 1798 was able to establish a monopoly of his company in Alaska, and from 1802 he became the main ruler of the Russian colonies in America (for more detail, see Grinëv 2020).

A year earlier Baranov faced a display of dissatisfaction among the promyshlenniki. Thus, in 1793 he sent two ships with the necessary materials and people to Voskresenskaya Bay on the south shore of the Kenai Peninsula for construction there of a fortified redoubt and a ship, and on July 1 arrived there himself to manage the work (RGAVMF, $\mathrm{f}$. 870, op. 1, d. 1784, 1. 56 ob.-57; Tikhmenev 1863: 2: 78-79, 86-87). The promyshlenniki sent there grumbled against the task of the governor. Work on construction of the Voskresenskii Redoubt and building the three-masted twenty-two-gun ship Feniks distracted them from their primary occupation-acquisition of furs from the natives, which substantially reduced their future income. Besides this, the Lebedev people led a hostile campaign against them. It brought some fruit: a conspiracy emerged among the workers at the shipyard, the development of which Baranov managed to stop with great difficulty by his personal presence and by the example of his endurance of all hardships and dangers of life in Alaska together with his subordinates, as he too risked his life during sea voyages and battles with Indigenous inhabitants (Tikhmenev 1863: 2:79).

In the fall of 1793, work at the shipyard was suspended and Baranov set off to winter over in the main Russian settlement on KodiakPavlovskaya Harbor (now the city of Kodiak)—leaving a detachment of promyshlenniki at the Voskresenskii Redoubt led by Ensign Ivan Rodionov. Over the course of the whole winter of 1793/94 the garrison of the redoubt was cut off from Kodiak: strong winter storms made impossible any communication with Pavlovskaya Harbor. The people in the redoubt became hungry and almost rebelled due to food scarcity. Only Rodionov's firm position, and then Baranov's arrival in May 1794 quenched the dissatisfaction that was seething among the promyshlenniki due to the lack of food and having to build a ship instead of the acquisition of furs (Tikhmenev 1863: 2:82).

The next year Baranov was again faced with unrest among the promyshlenniki, this time dissatisfied by the results of Shelikhov's 
division of the furs acquired during the preceding four-year period, as well as the numerous abuses, swindles, and shortchanges by his stewards. Baranov managed with difficulty to extinguish the social protest this time also, acknowledging the legitimacy of several of the claims of Shelikhov's workers (K istorii. . 1957: 63-95).

The frequent protests and unrest among Russian promyshlenniki of the Shelikhov company in Alaska in the 1790s were connected with the establishment of a colonial system in which once relatively free working people were turned into simple servants of the company under the harsh control of Baranov. In his practice he relied not only on the instructions of his chief, Shelikhov (he died in 1795) and his successors, but above all on methods of economic and physical coercion. The dependent natives—-the Aleuts and Kodiaks (Alutiiq)—especially suffered from harassment and violence of the stewards of the Shelikhov company since the Russians forced them to pursue sea otters in distant hunting grounds, to hunt foxes, seals, and walruses, to catch birds on steep cliffs, to stock up for the company fish, berries, and edible roots and bulbs, to participate in construction, and so on (Grinëv 2020: 28-42). We can surmise that this exploitation and violence provoked a reciprocal reaction. It was reflected in both passive and active forms: the natives fled and hid, and sometimes organized conspiracies and killed the Russian promyshlenniki supervising them. In one of his letters, Baranov mentions such an episode, when two indigenous people killed the promyshlennik Dmitriev. The perpetrators were seized, though one of them managed to escape later, the second, on Baranov's order, they let "run the gauntlet" a few times through his relatives, who beat him with sticks and baleen, after which the governor ordered him left shackled in chains, "in order to torment in work," but this one preferred to finish life with suicide (Tikhmenev 1863: 2:89).

The indigenous Alaskans, whom the Russians recruited for baidarka parties for hunting sea otters, at times willfully left the hunts and refused to work. Such a case occurred in 1795, which Baranov himself reported: "For flight of the Kenai toyon [chief] from Yakutat, I ordered him punished a bit and half his beard and mustache shaved off, to prevent disorder in the future, for he first showed a bad example and left willfully with ten baidarki of Kenai people, by which he deprived the company of the hunt" (Tikhmenev, 1861: 1:52). Shaving off mustache and beard was a shameful act, a temporary reminder of the chief's cowardice.

Orthodox missionaries tried to stand up in defense of the oppressed natives, but their attempts to complain to secular and spiritual author- 
ities were not crowned with success. ${ }^{3}$ In 1798 Hieromonk Makarii, together with several Aleuts, were able to reach even Emperor Paul I to tell him about the disastrous position of the native residents of the Russian colonies. However, his mission had almost no positive effects (Kliment 2009: 72-74). The tsar refused to limit the power of Baranov and to defend the oppressed Aleuts; instead, he ordered to send Hieromonk Macarii back to Alaska with a ban on leaving it without the permission of the higher authorities.

The missionaries' attempt, with the support of the interpreter Osip Pryanishnikov and navigator Gavriil Talin, to provoke defiance of the local Indigenous people on Kodiak in the absence of Baranov, who was wintering over on Sitka (now Baranof) Island in 1799/1800, also ended without results. Talin and Pryanishnikov, with the support of missionaries, wanted to reduce the exploitation of the local population, give the Indigenous people more freedom and provoke them to refuse to harvest furs for the Russians. Having returned in spring to Pavlovskaya Harbor, Baranov took the reins of management in his hands there; he immediately sent an armed detachment with the task of going around the whole island, list the natives and, "loading" (having given presents to) their toyons and "best men," to persuade (evidently, with the use of force) to again go with their relatives on the hunt for sea otters (Tikhmenev 1863: 2:149).

Baranov's position was further strengthened in 1799 after the formation, on the base of the conglomerate of Shelikhov companies, of the single monopolistic Russian-American Company (RAC) under the emperor's patronage. In 1802, Baranov was officially named governor of Russian America and received the rank of collegiate adviser. In this same year the RAC Board of Directors in St. Petersburg, using the monopolistic rights of the company, decided to enslave even more the Russian promyshlenniki, instructing Baranov to pay them henceforth with money instead of half shares, that is, not with furs, as before. All the furs, thus, fell into the hands of the company, with firmly established and, of course, reduced rates. The promyshlenniki were ultimately excluded from trading furs, turning them into hired hunting workers for the RAC. All this led them to violent protest. It took Baranov an enormous effort to calm the outraged people. With persuasion, threats, and often direct coercion, the governor forced many to sign the new general contract with the company, and for nonliterate promyshlenniki, not even asking their consent, Baranov's people signed, about which the promyshlenniki later complained to the government auditor V. M. Golovnin (1861a: 110, 125). 
Few of the ordinary Russian people, and even fewer of the dependent natives, dared to openly challenge the governor's authority. Saving themselves from the RAC's oppression, the Alaskans who lived in Ugashak Bay, in the north of the Alaska Peninsula, abandoned their settlement in 1803 and hid farther north (Rossiisko-Amerikanskaia kompaniia. . ., 1994: 161). Some Kodiak people committed suicide from despair and even killed their children, supposing that death for them was better than the ceaseless work for the company ("Zapiski ieromonakha Gedeona ...," 1994: 91). Others abandoned the hunt, usually in California, at whose shores the RAC began intensively hunting sea otters in the early 1800s. During the hunting expedition of Baranov's assistant I. A. Kuskov in 1808-1809, several Kodiak people ran off in California and others were thinking of following their example (Rossiia i SShA, 1980: 375-377; Khlebnikov, 1835: 126-127).

Several Russian promyshlenniki and sailors followed this method. In April 1806, during a stop in San Francisco Bay, two sailors-Mikhail Kal'yanin and Pëtr Polkanov-deserted from the crew of the RAC ship Yunona (Grinëv 2018a: 139). Among the Russian promyshlenniki who remained in Alaska passive protest against the RAC was sometimes manifested in the form of silent sabotage. Hieromonk Gedeon, who visited Russian America at the beginning of the nineteenth century, wrote that during the wreck of the ship Elizaveta on the shores of Kodiak in December 1805, the promyshlenniki refused to save the company property and it was only due to the aid of dependent natives that part of the ship's cargo was saved ("Zapiski ieromonakha Gedeona ...," 1994: 100).

\section{The Conspiracy of Naplavkov-Popov}

The harsh conditions of life in the colonies along with oppression and ruthless violence on the part of the colonial administration ultimately led to a conspiracy named after the chief instigators-the NaplavkovPopov conspiracy. It emerged in Novo-Arkhangel'sk on Sitka Island, where, in 1808, the capital of the Russian colonies had been transferred from Kodiak. Famine, which broke out in Novo-Arkhangel'sk in the winter of $1808 / 9$ and the severe punishments of the promyshlenniki (unjustified from their point of view) aggravated the already volatile situation by order of Baranov. Some of the workers (promyshlenniki) decided to start a rebellion in the fort following the example of Count Morits Benëvskii [Maurice Benyovszky], exiled to Kamchatka in 1770, who after being there a year led an uprising of exiles, seized a ship, and 
went in it to the Portuguese colony of Macao, and from there traveled on to France (Khlebnikov 1835: 128, 130). One of the two primary instigators of the conspiracy-steward Vasilii Naplavkov—knew this story well, having been exiled himself before this to Kamchatka. Another source of inspiration for the conspirators were the Cossack libertines of the time of Yermak and Sten'ka Razin: it is no accident that they named Ivan Popov, their second chief, "Khorunzhii" [a Cossack military rank] and formed their organization based on the principle of the Cossack circle (K istorii. . 1957: 167; Golovnin 1861b: 77-78).

The plans of Naplavkov, Popov, and their comrades were the following: they were going to murder the hated Baranov, his children, the navigator Ivan Vasil'ev who lived in the governor's house, and American skipper George Clark. Also, the Kodiak and Aleut elders loyal to Baranov would be subjected to this same fate in case of resistance. Then should follow the seizure of the whole fort and the ship Otkrytie in the port, on which the rebels, having loaded furs and taken on board thirty native "girls," were going to sail south to the Polynesian Islands (K istorii ... 1957: 166). They awaited only the return of a baidarka party sent to hunt sea otters in which some of their comrades participated.

Fortunately for Baranov, the plans of the rebels were told to him by three of the members of the conspiracy. This permitted the governor to unexpectedly appear at a secret gathering of the conspirators on July 26, 1809 , leading an armed detachment, just as they were preparing written obligations and signing up to participate in the uprising. Neither the ringleaders of the conspiracy nor their comrades were able to offer serious resistance at the arrest. Naplavkov, armed with a saber and pistol, did not dare to use them, and Popov had the courage only to tear up the ill-famed list of signatures, but the scraps of paper were collected, glued together, and subsequently attached to the case (Khlebnikov 1835: 129-130).

The participants in the conspiracy were seized and shackled in chains. After a brief preliminary investigation Baranov sent the five main rebels to Kamchatka. The RAC directors wanted to construct a show trial process, despite the request of their Kamchatka commissioner K. T. Khlebnikov not to inflate the affair, since many of the company's abuses could be revealed in court (Golovnin 1861b: 74). But the directors ignored his opinion. The case of the Naplavkov-Popov conspiracy stretched on for eight years. As Khlebnikov feared, it received rather broad publicity, especially after the materials of the case were demanded by the Siberian governor Ivan Pestel', an implacable enemy of the RAC, who evidently attempted to use them to compromise the company and 
Baranov personally. His attacks on the latter for excessive cruelty in relation to the promyshlenniki led to the fact that when the final verdict for the participants of the conspiracy was decided, the Committee of Ministers requested the tsar to send to the colonies a special official to investigate all the wrongdoings of the governor (RGAVMF, f. 166, op. 1, d. 4767, 1. 1; Bolkhovitinov 2005: 25-26). The emperor was personally aware of the course of the entire investigated affair; it was at his insistence the rebels were transferred to St. Petersburg. This was done for a more impartial trial; it was inappropriate to judge the conspirators in Siberia, since the Siberian governor-general Pestel was opposed to Baranov. In 1817 the local criminal court sentenced Naplavkov and Popov to hard labor in Siberia, and two of their comrades (another died during the course of the multiyear investigation) to exile in a settlement there (RGAVMF, f. 166, op. 1, d. 4767, 1. 1 ob.-2). And though the main rebels were convicted, this story strongly spoiled the image of the RAC in the eyes of the highest authorities and served as one of the reasons that forced the directors of the company to search for a replacement for Baranov at the post of governor of the colonies.

From the discussion above, we can see how the Naplavkov-Popov conspiracy was one of the most serious attempts at social protest in the history of Russian America. Information about the unsuccessful rebellion reached the highest authorities of the empire. In case of realization of the conspirators' goals the consequences could have been extremely negative, especially for Novo-Arkhangel'sk, located in the territory of hostile Tlingits, who would hardly have missed an opportunity to destroy the Russian fort, taking advantage of the absence of leadership and chaos reigning in it. The conspiracy left a painful impression on Baranov, and he urgently renewed his requests for dismissal, addressed to the RAC board of directors.

\section{Stabilization of the Social Situation and Protests}

In the 1810s, the Siberian authorities continued to receive complaints from the native residents of Russian America about the oppression and violence by the Russian promyshlenniki, RAC stewards, and commanders of the company ships. But the protests of the natives rarely reached their goal. The head of the Okhotsk port M. I. Minitskii openly conveyed this in his report of September 24, 1815 to the Irkutsk civil governor, writing "that it can positively be said that such complaints will never reach the Board of Directors even if the company were to 
last several hundred years more, and the Aleuts will forever remain in persecution and will always suffer from the Russian promyshlenniki, as they often now endure" (Spisok s raporta ..., 1861: 7). In particular, the elders of the Aleuts who visited Okhotsk in 1812 and 1814 complained to Minitskii about the exploitation, insults, and harassment from the uninvited new arrivals, who, as the archival document says, "forcibly take from the Aleuts various of their property, compel them to work without any pay, take away their wives and children, oppress them in their homes, swear and handle them like slaves" (Spisok s raporta..., 1861: 9). Although Minitskii took several measures and punished some of the guilty who arrived in Okhotsk from Russian America, he was not able to defend the Aleuts who lived in the distant islands. Incidentally, not only the natives but also the ordinary Russian promyshlenniki complained about the abuses of the RAC to the government auditor, Captain of 2nd Rank Golovnin, sent in 1817 to audit the affairs of the $\mathrm{RAC}$, the state of the Russian colonies in America, and investigate the accumulated complaints about the activity of the company and its administration (Golovnin 1861a: 124-125).

In January 1818, even before Golovnin's arrival in the colonies, the aged Baranov was replaced at his post by the commander of the RAC ship Kutuzov, Captain-Lieutenant Leontii fon Gagemeister (L. A. von Hagemeister), whom special council for the RAC Board of Directors in St. Petersburg commissioned to investigate the activity of the governor on the spot and if necessary to take from him management of the colonies (Bolkhovitinov 1975: 153-155; RGAVMF, f. 166, op. 1, d. 4767, 1. 29-30; Tikhmenev 1861: 1: 184). From this moment chief management of Russian America consisted exclusively of officers of the Naval Fleet, who established strict discipline and accountability, reduced the number of official abuses, and carried out a paternalistic policy in relation to the native population, which in some measure reduced the sharpness of social protest in the colonies. For prevention of potential conflicts and increase in dissatisfaction, the governors now either annually conducted an inspection of the different departments of the colonies themselves, or sent for this their assistants, endowed with broad powers. They usually listened to complaints by the promyshlenniki and natives, as well as the counterclaims of the representatives of the local administration, after which they adopted corresponding measures. In case of the legitimacy of the complaints, local leadership could receive warnings, reprimands, or even loss of their posts. At the same time, negligent or headstrong ordinary servants of the company, who systematically violated the orders of the immediate supervisor, were subject to more varied punishment: 
reprimands, deprivation of bonuses and incurrence of fines, arrest, public flogging, transfer to distant artels, and lastly, expulsion from the colonies (NARS. RRAC. Roll. 3, 68-70 passim; Sarafian 1971: 75-76, 91-98). And for the preservation of social stability the administration of the RAC over the extent of decades maintained constantly low prices on the basic foods, often at a loss, compensating these losses through markup on vodka, tobacco, clothing, and other wares that were exported to the colonies.

\section{The Situation with Social Protests in the Concluding Period of the Existence of Russian America, 1818-1867}

Lieutenant Semën Yanovskii, who replaced Hagemeister at the post of governor of Russian America in October 1818, conducted an inspection trip in the summer of 1819 from Novo-Arkhangel'sk to the islands of Kodiak and Unalaska, visiting at the same time the Pribilof Islands, where not long before this unrest had occurred among the local Russians and Aleuts. As a result of the rebellion-a small scale riot not accompanied by armed clashes - the head of the island of St. Paul, Pëtr Batuev, was removed from authority for abuses and assault, especially during his drunken outbursts; and one of the Aleuts-Nikolai Ustyugov-even tried to establish there, according to Yanovskii, an independent republic; he refused, along with his followers (about thirty men), to work for the RAC, promising that now they could obtain from foreign ships everything necessary. Incidentally, this social protest soon ended on its own because of the despotic inclinations of Ustyugov, and the Aleuts, to the satisfaction of the governor, returned under RAC control. In the place of Batuev, who had discredited himself, Yanovskii appointed Ignatii Cherkashenin as manager on the island of St. Paul (NARS. RRAC. Roll. 27, 10 ob.-11).

In 1825 the new governor Pëtr Chistyakov had to face unrest among the Aleuts and Kodiak people who lived in Novo-Arkhangel'sk. Having learned that their old enemies and rivals, the Tlingit, received an increase at the sale of furs to the company, the Aleuts and Kodiak people began to openly express their discontent. To calm them, Chistyakov took the responsibility on himself and without the sanction of the Board of Directors ordered the price of furs obtained from dependent natives increased one and a half times. The governor feared that otherwise they would completely lose the incentive to work, and it would be necessary to recruit them by force into hunting parties for procuring sea otters, as 
was sometimes done in Baranov's time (NARS. RRAC. Roll. 30, 49-50). The Board of Directors supported Chistyakov in this and in 1827 approved the new rate. Thus, if the Kodiak people received only 10 rubles for the hide of a sea otter in goods or RAC tokens as previously, then from 1829, when the new rate took force, it was twenty rubles, and the Unalaska Aleuts correspondingly began to deliver silver fox hides at six rubles each (before this the current rate priced them at two rubles fifty kopecks, the 1825 rate at four rubles) (Khlebnikov 1979: 40-42, 46, 118, 182). Incidentally, the introduction of the new rate did not go without unrest and protests among the Aleuts of the Atka Department who insisted on equal pay for furs with Aleuts of the Near Islands, who received thirty rubles each for a sea otter hide. Chistyakov, who was faced with unrest, ordered "for ceasing this in the future and for greater encouragement of the Aleuts toward sea otter hunting" the same rate introduced in the summer of 1830 (NARS. RRAC. Roll. 32, 13 ob.-14).

Socioeconomic protest of the native population of the colonies sometimes led to an increase in its material position. But this did not always occur, even by reason of the psychological pressure to which dependent natives were subjected by the stewards and local RAC administration, who intimidated or persuaded local residents to refuse complaints and demands. Baron Ferdinand von Wrangell, who replaced Chistyakov, visited the Kodiak Department in the summer of 1831 during an inspection trip and reported to the RAC Board of Directors about the Kodiak people: "These people are so intimidated [by the RAC stewards] that it cost me no little patience to loosen their tongues so they could tell me their needs. They complained of mortality, reduction in procurement, about the rule based on which an Aleut who found a cast up [on the shore] whale does not receive even a piece of meat, about oppression in payment [for procured fur and for work for the $\mathrm{RAC}$, about the shortage of guns and powder, and about debts listed by the Office, but not known to the debtors" (NARS. RRAC. Roll. 34, 172-172 ob.). Wrangell was able only partially to satisfy the hopes of the local natives, refusing to increase payments for furs, he twice raised the payment for whales procured by the natives and petitioned the Board of Directors to cancel the debts of the Aleuts. Then visiting the Pribilof Islands and listening to the complaints of the local residents, Wrangell ordered pay raised for procurement there of fur seals and added 10 rubles to the salary (25 rubles per year) of Aleut women who worked there (NARS. RRAC. Roll. 34, 178-179 ob.).

Sometimes as a result of repeated complaints by the dependent natives, the colonial administration was removed from their posts 
heads of artels and even trade redoubts. For example, in 1819 the head of the Karluk artel, Aleksei Lopatin, was removed from duty for harsh relations with the Kodiak people, and in 1845, as a consequence of dissatisfaction and numerous complaints of the Chugach, Pëtr Naumov, the head of the Konstantinovskii Redoubt, lost his post (NARS. RRAC. Roll. 27, 16; Roll. 51, 208).

Condescendingly accepting complaints and requests from the dependent natives, the colonial administration, in case of open disobedience to orders by a local leader, did not hesitate to resort to threats or to use of repressions, which occurred, though very rarely. For example, when in 1851 the Aleuts on Unga Island refused to carry out the order of the manager of the island, Andrei Arkhimandritov, to go on a sea otter hunt, as punishment for disobedience the governor Captain of 2nd Rank Nikolai Rozenberg ordered the perpetrators flogged (Sarafian 1971: 156).

But the corporal punishment never happened with independent natives. For example, in the mid-1850s the governor of Russian America, Captain of 1st Rank S. V. Voevodskii, forbid the chiefs of the Tlingit people free access to the port of Novo-Arkhangel'sk and trade there. This brought on the dissatisfaction of the Tlingit and even led to a kind of strike; the Tlingit, as a sign of protest, refused to work at procuring and transporting ice to the port (which the RAC then sold in California) or to deliver firewood and fresh food for the residents of Novo-Arkhangel'sk. The mutual intransigence of Voevodskii and the Tlingit ultimately led to a large clash between the Indigenous peoples and the Russian soldiers, sailors, and employees of the RAC at the walls of Novo-Arkhangel'sk in March 1855 (NARS. RRAC. Roll. 60, 73-77; Tikhmenev 1863: 2:207-208).

Immigrants from Russia, among whom since the 1820s were many natives of the Grand Duchy of Finland, expressed dissatisfaction with their position usually in two ways-either by means of filing complaints, or by means of flight (desertion). These forms of passive social protest were well known in the Russian Empire of that time. The favorite place of fugitives was, as before, California, where in 1812 the Russians founded the settlement of Fort Ross. However, the colonial administration usually denied social protest as a reason for desertion, since in such cases the responsibility rested directly on it. Thus, in a dispatch of January 18, 1822, No. 45, to the RAC Board of Directors, Captain-Lieutenant Matvei Murav'ëv wrote: "At Ross a very unpleasant affair occurred: six Russian men and particularly carpenters, whom I sent for construction, on December 12 having stolen Company guns 
and a supply of powder, fled according to the report of [manager] Shmidt and according to the stories of other people who arrived here [in Novo-Arkhangel'sk] for no reason other than the turbulence of their character and of course they are not all equally guilty, I suppose that Malyavin and Volkov are instigators" (NARS. RRAC. Roll. 28, 4 ob.). One of the fugitives was subsequently returned to the colonies and sent in exile to the Pribilof Islands (NARS. RRAC. Roll. 29, 206), the others remained among the Mexicans. Another deserter-Prokhor Egoroveven raised a rebellion among the Indigenous Californians, directed against the Catholic missions and local authorities. Incidentally, the rebellion was quickly suppressed and Egorov was killed by indigenous rebels (Grinëv 2018a: 141-142; Sarafian 1971: 82-85).

Protests also occurred transnationally. The desertion of the employees of the Russian-American Company had a wider geography and was not limited to California, although it was the main place for escapes. Occasionally natives of Russia deserted in ports of other Latin American countries or in the Hawaiian Islands, where servants of the RAC arrived on company ships. In this case the colonial leadership rejected social protest as a reason for desertion. As P. E. Chistyakov reported to the Board of Directors in a dispatch of May 15, 1830, No. 141, during the voyage of the brig Baikal to Chile for food supplies, five men of the crew jumped ship. In the governor's opinion, the reason for this was the beauty of the local women (NARS. RRAC. Roll. 32, $170 \mathrm{ob}$.). To combat desertion, the colonial leadership tried by means of recruiting many naval sailors into the service, as well as assigning to the crews of ships servants who had a family or persons who had credit with the company (Sarafian 1971: 89-90).

Later, in the second half of the 1830s, when the English trading posts of the Hudson's Bay Company moved closer to the borders of Russian America, runaways also went to the English in Canada. For example, such an attempt to flee was made by two Russians and two Finlanders from the crew of the brig Aktsiya, which wintered over at Dionisievskii Redoubt in 1837/8 (NARS. RRAC. Roll. 41, p. 85). The Finlanders were generally distinguished by a greater inclination to get away: accustomed to more freedom and liberties in their homeland than the Russians, they resented the strict discipline and incessant work for the RAC. For example, as early as 1827 the Finnish native Matvei Tomasov (probably, Matias Thomasson) tried to leave NovoArkhangel'sk, secretly stowing aboard the American brig Active, but was returned by the crew of the ship to the Russian administration (RGIA, f. 18, op. 5, d. 1282, 1. 3-5). In a similar way, but more successfully, 
Isaak Nikodemuson escaped in January 1854, entering unnoticed the American bark Ella Francis in the Novo-Arkhangel's port, on which then he went to San Francisco (Grinëv 2018a: 141). And a year before this four Finlanders fled south from Novo-Arkhangel'sk into British possessions in a stolen skiff, having taken with them some property of the RAC (mostly ammunition) (NARS. Roll. 59, 61-62, 346 ob.). In the governor's opinion, they hastened to California (NARS. Roll. 59, 346 ob.), where at that time the famous gold rush raged. It is difficult to say whether social protest against a painful life in the capital of the Russian colonies occurred in this case or simply the desire to cash in on the gold mines. Possibly both motives were in effect.

Desertion as a form of social protest was occasionally practiced by foreign sailors who arrived on the shores of Russian America for trade with the indigenous nations, Inuit, and Russians or for the purpose of hunting whales. Thus, in a report of May 9, 1822 Governor M. I. Murav'ëv reported that in the port of Novo-Arkhangel'sk the crew rebelled on the ship Sultan of the American skipper George Clark and ten sailors went ashore where they entered temporary service for the RAC (NARS. Roll. 28, 64 ob.-65). The economic stimulus was not effective enough to keep them for long in the colonies since the salary of the RAC was less than half of what they had received on American ships (Khlebnikov1985: 138).

Desertion was one of the extreme forms of passive social protest and the inhabitants of the Russian colonies turned to it rather rarely. More widespread forms were traditional complaints and petitions directed to the higher administration, which reflected protest against the conditions of work and way of life, abuses of local leadership, unjust orders, and so on. Examples can easily be found in the documents. For example, after the visit in July 1832 of the Novo-Aleksandrovskii Redoubt at the mouth of the Nushagak River, Wrangell wrote: "The crew expressed its displeasure and brought me complaints about the manager: but the claims were in large part unfounded" (NARS. RRAC. Roll. 34, 345 ob.). Nevertheless, several stewards, managers of hunting artels, and even departments lost their places because of complaints of subordinates. For example, in 1833 I. I. Sizykh was taken from the post of director of the Atka office because of abuses, and in 1846 the steward of the trade store in Novo-Arkhangel'sk, Maksim Smolin, was removed from duty for repeated complaints by his customers about dishonesty (NARS. RRAC. Roll. 35, 179-180; Roll. 52, 112 ob.).

Just as in cases with the dependent natives, the colonial administration tried to be attentive to complaints of subordinates, while at the 
same time, refusal to obey an order of an immediate superior was sometimes punished rather severely. Thus, in May 1830 Governor Chistyakov ordered three servants of the company who had repeatedly sabotaged the orders of the manager of the redoubt, Pëtr Epifanov, sent to Kodiak from the Nikolaevskii Redoubt and punished them publicly with flogging for malicious disobedience (NARS. RRAC. Roll. 32, 150-150 ob.; Sarafian 1971: 91).

Social protest in the colonies was resisted not only by a system of punishments, but also by widespread denunciation, which was strongly encouraged by the colonial leadership. For example, Governor N. Ya. Rozenberg expressed gratitude to the head of the hunting party Gavrila Prokop'ev "for the fact that he did not hide from the leadership the unauthorized action of the Atka Aleut David Platonov and his son Ivan, who left the party for a while not only without permission of the Party Leader, but even without his knowledge" (NARS. RRAC. Roll. 57, 64-64 ob.). For unauthorized abandonment of the hunt Rozenberg ordered each of the disobedient men punished publicly by twenty-five blows of the rod.

The midshipman K. S. Zelenoi, who visited Pavlovskaya Harbor on Kodiak at the end of September 1863 in the naval clipper Abrek, also attested to the role of denunciations in the daily life of the colonies. The young sailor characterized especially negatively the relations of the RAC with the local residents: "On all sides here, whoever you talk to, you hear complaints about the company; but incidentally the local inhabitants do not always unburden themselves by this: everything here is so clogged, so constricted, that storytellers tell you about their lives, looking back; whoever listens, denounces. The spy system there is in full swing" (Zelenoi 1865: 56-57).

Almost constant silent discontent, and sometimes even murmurs, was brought on by the chronic shortage of goods in the colonies because of the irregular delivery of many necessary foods and wares, often of bad quality, and equally because of excessively high prices, assigned for them by the RAC leadership. The government auditor Sergei Kostlivtsov eloquently attested to the quality of the goods imported into the colonies: "Ready-made clothes and shoes for the common people exceed any likelihood by their bad quality, so that boots last only a few days, and a cloth dress no more than two months" (Prilozheniya k dokladu ..., 1863: 106). Additional dissatisfaction was brought on by the system of distribution of goods and foods, in which those who most benefitted were always representatives of the local administration. Therefore, despite various efforts of the colonial leadership to eradicate social protest or at 
least to reduce it to a minimum - to achieve its full disappearance was impossible-the whole socioeconomic policy and practice of the RAC constantly provoked the dissatisfaction of people and consequently led if not to open, then to covert social protest. Thus, some Aleuts and Kodiak people, not having the possibility to profitably sell sea otter hides, kept them for themselves, and would not give them to the RAC for the paltry fee that was attested by Nikolai Benzeman, a lieutenant of the Corps of Fleet Navigators (RGAVMF, f. 17, op. 1, d. 261, 1. 90). The dependent natives were occupied in this case with sabotage, protesting by such passive method against the economic policy of the RAC. At the beginning of the 1860s the abbot of the Kenai Mission Nikolai wrote about an analogous situation among the Tanaina (Dena'ina) people: "The whole operation of trade is in the company's hands; as a result, the natives reluctantly hunt-are dissatisfied with the pay for their goods. ... Indeed, for example, sables [martens] here are very many and good, but they almost do not hunt them; only the boys procure them instead for fun; from the good ones they sew parkas for themselves, and the worst they bring to the company. They say: 'They will still give a ruble, the company has no eyes" (Yakimov 2001: 227).

The dependent natives for their part were periodically occupied with covert sabotage because of low pay for dressing the hides of fur-bearing animals, which had negative economic consequences. Furs with an initially high quality lost it in the process of inept, hasty, and careless handling, which was a consequence of lack of interest in their work by the native workers. On March 22, 1850 Governor Mikhail Teben'kov was forced to issue a special circular on this occasion, which required allotting more attention to proper cleaning and dressing of hides. Despite this, a substantial part of the hides received in 1851 from the Unalaska Department had damage from careless handling, and part was moth-eaten, which forced Rozenberg to give special instructions to Unalaska. In it he asked the manager of the island to communicate to the local Aleuts, that if they henceforth continued to negligently treat the skinning and dressing of hides, then he would be forced to resort to nonverbal "rebukes," that is, to corporal punishment (NARS. RRAC. Roll. 57, 179 ob.-180 ob., 286-286 ob.).

\section{Conclusion}

Summing up the results of the research undertaken, it is possible to arrive at the following conclusions. The most frequent reasons for pro- 
tests in Russian America were the actions of the colonial administration or the abuses of its individual representatives, as well, of course, as the dissatisfaction of the material position, norms, conditions, pay for work, and supplying of a substantial part of the population of the Russian colonies. Nevertheless, on the whole protest activity in Russian America was not significant, as well as the involvement of employees of the RAC and dependent natives in local and temporary movements of protest. Its primary forms were complaints, economic sabotage, and desertion (usually outside the Russian colonies).

The practice of social protest in Russian America was radically different from the situation in the colonial possessions of other states. For example, if in the early stages of Canada's development, the French disagreed with the colonial administration they could go into the woods and become coureurs de bois (Akimov 1999: 214-215), whereas nothing like that was known in Russian America. Neither the Russian promyshlenniki nor the dependent natives usually tried to hide in the territory of Alaska when escaping. This was hindered by the harsh natural conditions, the relative scarcity of food resources, and the need to store food for the long winter season, and often the hostility of the neighboring natives. In addition, to block the actions of the natives the Russians resorted to the practice of hostage-taking (especially in the early period of colonization), and strongly encouraged informing (for more, see Grinëv 2003a, 2003b). If the British colonists began the war for the independence of the United States in 1775, there was not even a hint of any struggle for the freedom of Alaska. The root causes of weak protest activity in the Russian colonies were evidently in the very nature of the socioeconomic system in Russia, where from childhood people were educated in the spirit of submissiveness to the supreme power. This system, with some changes, was then reproduced in Alaska and acknowledged by dependent Indigenous peoples who converted to Christianity. The manifestation of social protest was also blocked by a whole system of negative and positive sanctions by the colonial administration.

Protests in Russian America never assumed an extensive character but rather covered a maximum of several dozen men. The greatest number of protest occurrences belongs to the 1790s-1800s, when the establishment of the colonial system took place, and exploitation of dependent natives and Russian promyshlenniki reached its apogee. Later, after the arrival to power in the colonies of naval officers (from 1818), the situation began noticeably to improve: management and accountability became much more ordered, reducing the number of 
official abuses and the like. The policy toward dependent natives attained a clearly manifested paternalistic tint, and emigrants from the homeland obtained the possibility of presenting their claims in accordance with the bureaucratic order approved in the empire or by means of direct complaints to representatives of the highest administration of the colonies. For their part, the colonial authorities tried in every way to block protest activity and not bring the affair to open manifestations of discontent, especially violent forms, since as a result hunting and trade could suffer, and ultimately the profits of the RAC and its image in the eyes of tsarist authorities. Therefore, the colonial authorities used surveys of the dissatisfied, examination of complaints, contents of denunciations, and the results of spying for taking preventative measures to avoid the escalation of social protest. As historical experience showed, the activity of the colonial administration in this direction generally proved effective.

\section{Acknowledgment}

The research is partially funded by the Ministry of Science and Higher Education of the Russian Federation as part of World-class Research Center program: Advanced Digital Technologies (contract No. 075-152020-934 dated 17 November 2020).

Andrei Val'terovich Grinëv is a Doctor of Historical Sciences and Professor in the Department of Social Sciences at Petersburg Polytechnic University, in St. Petersburg, Russia. He is the author of more than 270 scholarly publications, primarily history and ethnology of Russian America. These include about 200 scholarly articles published in Russia, the United States, Canada, Western Europe, Japan, and China, as well as several monographs.

Richard L. Bland is an archaeologist at the Museum of Natural and Cultural History at the University of Oregon. He has translated approximately 200 articles and 30 books into English, including Warfare in the Russian Arctic: The Military History of Chukotka from the Early 1st Millennium to the 19th Century (2020), Russian Colonization of Alaska (2018, 2020), and Geoarchaeology \& Radiocarbon Chronology of Stone Age Northeast Asia (2016). Email: rbland@uoregon.edu. 


\section{Notes}

1. Gross contract is the official name of all contracts entered into by merchants and promyshlenniki involved in the organization of hunting companies

2. This phrase is an old Russian expression that corresponds to rape.

3. Missionaries periodically came into conflict with Baranov and his people, protesting against the cruel exploitation of the indigenous Alaskans until 1805, when the chamberlain Rezanov who arrived in the colonies forbid them to oppose the decisions of the main ruler.

\section{References}

\section{Archival Sources}

ARGO-Arkhiv Russkogo geograficheskogo obshchestva (Archive of the Russian Geographic Society), St. Petersburg.

AVPRI-Arkhiv vneshnei politiki Rossiiskoi imperii [Archive of Foreign Affairs of the Russian Empire], Moscow.

NARS-National Archives and Record Service, Washington, DC. Records of the Russian-American Company.

RGAVMF-Rossiiskii gosudarstvennyi arkhiv Voenno-Morskogo flota [Russian State Archive of the Naval Fleet], St. Petersburg.

RGIA-Rossiiskii gos. istoricheskii arkhiv [Russian State Historical Archive], St. Petersburg.

\section{Secondary Sources}

Akimov, Yu. G. 1999. Ocherki rannei istorii Kanady [Essays on Canadian Early History]. St. Petersburg: Izd. Vird.

Bashkina, N. N., N. N. Bolkhovitinov, J. H. Brown, I. I. Kudryavtsev, N. B. Kuznetsova, R. D. Landa, V. N. Ponomarev, Ch. S. Sampson, N. V. Ushakova, J. D. Hardgrowe, eds. 1980. Rossiia i SShA: stanovlenie otnoshenii, 1765-1815 [Russia and the USA: Establishment of relations. 1765-1815]. Moscow: Nauka.

Blinov, A. I., I. M. Kuraev, O. N. Mukhina, and P. I. Pavlov, eds. 1957. K istorii Rossiisko-Amerikanskoi kompanii [On the history of the Russian-American company]. Krasnoyarsk: Krasnoyarskii gos. arkhiv.

Bolkhovitinov, N. N. 1975. Russko-amerikanskie otnosheniia, 1815-1832 [RussianAmerican Relations, 1815-1832]. Moscow: Nauka.

Bolkhovitinov, N. N., ed. 2005. Rossiisko-Amerikanskaia kompaniia i izuchenie Tikhookeanskogo Severa, 1815-1841 [The Russian-American Company and study of the North Pacific Ocean, 1815-1841]. Moscow: Nauka. 
Dement'eva I. N. 2013. “Teopetiko-metodologicheskie podkhody k izucheniiu sotsial'nogo protesta v zarubezhnoi i otechestvennoi nauke" [Theoretical and methodological approaches to the research of social protest in foreign and Russian science]. Monitoring obshchestvennogo mneniia 4: 3-12.

Golovnin, V. M. 1861a. "Zapiska kapitana 2-go ranga Golovnina o sostoianii Rossiisko-Amerikanskoi kompanii v 1818 godu" [The notes of Captain of 2nd Rank Golovnin on the state of the Russian-American Company in 1818]. In Materialy dlia istorii russkikh zaselenii po beregam Vostochnogo okeana, Issue 1. St. Petersburg: n.p.

Golovnin, V. M. 1861b. "Zamechaniya V. M. Golovnina o Kamchatke i Russkoi Amerike" [Observations of V. M. Golovnin on Kamchatka and Russian America]. In Materialy dlia istorii russkikh zaselenii po beregam Vostochnogo okeana, Issue 2. St. Petersburg: n.p.

Grinëv A. V. 2003a. "A fifth column in Alaska: Native collaborators in Russian America." Alaska History 22 (1-2): 1-21.

Grinëv A. V. 2003b. "Native Amanaty in Russian America." European Review of Native American Studies 17 (1): 7-20.

Grinëv A. V. 2013. "The first Russian settlers in Alaska." Historian 75 (3): 443-474.

Grinëv, A. V. 2018a. "Deserters and fugitives in Russian America." Arctic Anthropology 55 (2): 134-151.

Grinëv, A. V. 2018b. Russian colonization of Alaska: Preconditions, discovery and initial development, 1741-1799. Lincoln: University of Nebraska Press.

Grinëv A. V. 2020. Russian colonization of Alaska: Baranov's Era, 1799-1818. Lincoln: University of Nebraska Press.

Kelas'ev O. V., S. V. Kazakov, and A. Y. Leyes. 2006. "Spetsifika kommunikatsii vlasti i naseleniia v kontekste massovogo publichnogo protesta" [A specific of communication between the power and peoples in the context of mass public protest]. Zhurnal sotsiologii i sotsial'noi antropologii 9 (1): 103-122.

Khlebnikov, K. T. 1835. Zhizneopisanie Aleksandra Andreevicha Baranova, Glavnogo pravitelia Rossiiskikh kolonii v Amerike [Biography of Alexander Andreevich Baranov, governor of the Russian colonies in America]. St. Petersburg: Morskaia tip.

Khlebnikov, K. T. 1979. Russkaia Amerika v neopublikovannykh zapiskakh K.T. Khlebnikova [Russian America in the unpublished notes of K. T. Khlebnikov]. Leningrad: Nauka.

Khlebnikov, K. T. 1985. Russkaia Amerika v "zapiskakh" Kirila Khlebnikova: Novo-Arkhangel'sk [Russian America in the "notes" of Kirill Khlebnikov: Novo-Arkhangel'sk]. Moscow: Nauka.

Kliment (Kapalin), Metropolitan. 2009. Russkaia Pravoslavnaia Tserkov' na Aliaske do 1917 goda [The Russian Orthodox Church in Alaska up to 1917]. Moscow: OLMA Media Grupp. 
Makarova, R. V. 1968. Russkie na Tikhom okeane vo vtoroi polovine XVIII v. [Russians on the Pacific Ocean in the second half of the 18th century]. Moscow: Nauka.

Mironov B. N. 2015. Rossiiskaia imperiia: Ot traditsii k modernu [Russian empire: From traditions to modernity]. Vol 2. St. Petersburg: Dmitrii Bulanin.

Prilozheniia $k$ dokladu Komiteta ob ustroistve russkikh amerikanskikh kolonii [Appendices to the report of the committee on the structure of the Russian American colonies]. 1863. St. Petersburg: Tip. Departmenta vneshnei torgovli.

Rossiisko-Amerikanskaia kompaniia i izuchenie Tikhookeanskogo Severa, 1799-1815. Sbornik dokumentov [The Russian-American Company and the study of the North Pacific Ocean, 1799-1815. Collection of documents]. 1994. Moscow: Nauka.

Sarafian, W. L. 1971. Russian-American company employee policies and practices, 1799-1867. Ph. Ann Arbor, Michigan: University Microfilms.

Spisok s raporta Okhotskago portovago nachal'nika k Irkutskomu grazhdanskomu gubernatoru, ot 24 sentyabrya 1815 g., No. 1931 [Copy of the Report from the Head of the Okhotsk Port to the Irkutsk Civil Governor, of September 1815, No. 1931]. 1861. Materialy dlya istorii russkikh zaselenii po beregam Vostochnago okeana [Materials on the History of Russian Settlements along the Shores of the Eastern [Pacific] Ocean]. Issue 1. St. Petersburg: n.p.

Tikhmenev, P. A. 1861 \& 1863. Istoricheskoe obozrenie obrazovaniia Rossiisko-Amerikanskoi kompanii i deistvii ee do nastoiashchego vremeni [Historical Survey of the Formation of the Russian-American Company and Its Activities up to the Present Time]. Pt. 1 \& 2. St. Petersburg: Tipografiia Eduarda Veimara.

Yakimov, O. D. 2001. Nikolai Militov—igumen kenaiskoi pravoslavnoi missii" [Nikolai Militov-Abbot of the Kenai Orthodox Mission]. Russkaya Amerika i Dal'nii Vostok (konets XVIII v.-1867 g.). K 200-letiyu obrazovaniya RossiiskoAmerikanskoi kompanii. Materialy mezhdunarodnoi nauchnoi konferentsii (Vladivostok, 11-13 oktyabrya 1999 g.) [Russian America and the Far East (End of the 18th Century-1867). On the 200th Year of the Formation of the Russian-American Company. Materials for the International Science Conference (Vladivostok, 11-13 October 1999)]. (pp. 208-129). Vladivostok: DVO RAN.

Zapiski ieromonakha Gedeona o Pervom russkom krugosvetnom puteshestvii i Russkoi Amerike, 1803-1808 gg. [The notes of Hieromonk Gedeon on the first Russian round-the-world voyage and Russian America, 1803-1808]. In Dridzo, A. D. and R. V. Kinzhalov (Eds.). Russkaya Amerika. Po lichnym vpechatleniyam missionerov, zemleprokhodtsev, moryakov, issledovatelei i drugikh ochevidtsev (pp. 27-121). 1994. Moscow: Mysl'.

Zelenoi, K. S. 1865. Iz zapisok o krugosvetnom plavanii (1861-1864) [From the Notes on an Around-the-World Voyage (1861-1864)]. Morskoi sbornik 80 (9): $56-57$. 